\title{
Haloperidol Regulates the State of Phosphorylation of Ribosomal Protein S6 via Activation of PKA and Phosphorylation of DARPP-32
}

\author{
Emmanuel Valjent ${ }^{1,6}$, Jesus Bertran-Gonzalez ${ }^{2,3,4}$, Heather Bowling ${ }^{5}$, Sébastien Lopez', Emanuela Santini', \\ Miriam Matamales ${ }^{2,3,4}$, Alessandra Bonito-Oliva', Denis Hervé2,3,4, Charles Hoeffer ${ }^{5}$, Eric Klann ${ }^{5}$, \\ Jean-Antoine Girault ${ }^{2,3,4}$ and Gilberto Fisone*,1 \\ 'Department of Neuroscience, Karolinska Institutet, Stockholm, Sweden; ${ }^{2}$ INSERM, UMR-S839, Paris, France; ${ }^{3}$ Université Pierre et Marie Curie, \\ Paris, France; ${ }^{4}$ Institut du Fer à Moulin, Paris, France; ${ }^{5}$ Center for Neural Science, New York University, New York, NY, USA
}

Administration of typical antipsychotic drugs, such as haloperidol, promotes CAMP-dependent signaling in the medium spiny neurons (MSNs) of the striatum. In this study, we have examined the effect of haloperidol on the state of phosphorylation of the ribosomal protein S6 (rpS6), a component of the small 40S ribosomal subunit. We found that haloperidol increases the phosphorylation of rpS6 at the dual site Ser235/236, which is involved in the regulation of mRNA translation. This effect was exerted in the MSNs of the indirect pathway, which express specifically dopamine D2 receptors (D2Rs) and adenosine A2 receptors (A2ARs). The effect of haloperidol was decreased by blockade of A2ARs or by genetic attenuation of the $\mathrm{G} \alpha_{\text {olf }}$ protein, which couples A2ARs to activation of adenylyl cyclase. Moreover, stimulation of cAMP-dependent protein kinase A (PKA) increased Ser235/236 phosphorylation in cultured striatal neurons. The ability of haloperidol to promote rpS6 phosphorylation was abolished in knock-in mice deficient for PKA activation of the protein phosphatase-I inhibitor, dopamine- and cAMP-regulated phosphoprotein of $32 \mathrm{kDa}$. In contrast, pharmacological or genetic inactivation of p70 rpS6 kinase I, or extracellular signal-regulated kinases did not affect haloperidol-induced rpS6 phosphorylation. These results identify PKA as a major rpS6 kinase in neuronal cells and suggest that regulation of protein synthesis through rpS6 may be a potential target of antipsychotic drugs.

Neuropsychopharmacology (20II) 36, 256I-2570; doi:10.1038/npp.20II.I44; published online 3 August 20II

Keywords: antipsychotics; adenosine A2A receptor; dopamine D2 receptor; medium spiny neurons; protein phosphatase- I; striatum

\section{INTRODUCTION}

The ability to antagonize neurotransmission at dopamine D2 receptors (D2Rs) is generally regarded as an important feature of drugs used in the treatment of schizophrenia and other psychotic disorders (Creese et al, 1976). However, blockade of D2Rs leads to the development of irreversible side effects, including tardive dyskinesia and parkinsonism, which seriously hamper the use of effective medications. These motor disorders have been proposed to depend on the ability of antipsychotic drugs to affect neurotransmission in the dorsal striatum, a major component of the basal ganglia (Robertson and Fibiger, 1992; Wan et al, 1995).

*Correspondence: Dr G Fisone, Department of Neuroscience, Karolinska Institutet, Retzius väg 8, 17177 Stockholm, Sweden,

Tel: + 46852487375 , Fax: + 46832 0988,

E-mail: gilberto.fisone@ki.se

${ }^{6}$ Current address: Institut de Génomique Fonctionnelle, INSERM U66I, CNRS UMR 5203, University Montpellier I and II, Montpellier, France. Received 23 February 201।; revised I3 May 20 II; accepted 23 June 2011
In this region, D2Rs are selectively expressed by a large group of GABAergic medium spiny neurons (MSNs), which project to the external segment of the globus pallidus (Gerfen, 1992). Acting through a polysynaptic circuit, these cells modulate the activity of thalamo-cortical neurons involved in the control of motor function (Albin et al, 1989; Gerfen, 1992). For these reasons, striatopallidal MSNs are thought to have a critical role in the motor side effects associated to the use of antipsychotic drugs.

One of the primary actions exerted in the brain by conventional antipsychotics, such as haloperidol, is to promote cAMP-dependent signaling, which is normally inhibited by D2Rs through activation of $\mathrm{G}_{\mathrm{i} / \mathrm{o}}$ proteins (Stoof and Kebabian, 1981). In striatopallidal MSNs, haloperidolinduced activation of cAMP-dependent protein kinase A (PKA) and of the protein phosphatase-1 (PP-1) inhibitor, dopamine- and cAMP-regulated phosphoprotein of $32 \mathrm{kDa}$ (DARPP-32), has been proposed to affect gene transcription by acting on nuclear targets, including the cAMP response element-binding protein and histone $\mathrm{H} 3$ (Bertran-Gonzalez et al, 2009; Konradi and Heckers, 1995; Li et al, 2004; 
Pozzi et al, 2003). Much less is known about the ability of antipsychotic drugs and of the PKA/DARPP-32 cascade to affect signaling cascades involved in translational control.

The ribosomal protein S6 (rpS6) is a component of the small 40S ribosomal subunit implicated in mRNA decoding (Ruvinsky and Meyuhas, 2006). rpS6 is phosphorylated at multiple sites, comprised between Ser235 and Ser247, by the p70 rpS6 kinase (S6K) 1 (Bandi et al, 1993; Krieg et al, 1988), which is a major downstream effector of the mammalian target of rapamycin complex 1 (mTORC1) (Costa-Mattioli et al, 2009). Phosphorylation of rpS6 at the dual site Ser235/236 occurs also independently of mTORC1, via the p90 ribosomal S6 kinases (RSK), which are activated by the extracellular signal-regulated kinases (ERK) (Roux et al, 2007; Sturgill et al, 1988). Recent studies performed in pancreatic $\beta$-cells identified PKA as an additional rpS6 kinase, specifically involved in the phosphorylation of Ser235/236 (Moore et al, 2009).

S6K-dependent phosphorylation of rpS6 has an important role in the control of cell size (Pende et al, 2004; Ruvinsky et al, 2005) and protein synthesis-dependent plasticity, such as long-term potentiation (Antion et al, 2008). In addition, phosphorylation at Ser235/236 has been proposed to promote protein synthesis by facilitating rpS6 recruitment to the $5^{\prime}$ cap complex, during the formation of the preinitiation translation complex (Roux et al, 2007). In this study, we examined the ability of haloperidol to regulate rpS6 phosphorylation in the MSNs of the dorsal striatum. We show that haloperidol increases the phosphorylation of rpS6 at Ser235/236, and that this effect is independent of ERK- and mTORC1-mediated activation of S6K1, but requires intact PKA/DARPP-32 signaling.

\section{MATERIALS AND METHODS}

\section{Animals}

Male C57BL/6J mice (25-30 g) were purchased from Taconic (Tornbjerg, Denmark). Bacterial artificial chromosome transgenic mice expressing EGFP under the control of the promoter for the D2R (Drd2-EGFP) or the dopamine D1 receptor (D1R; Drd1a-EGFP) were generated by the GENSAT (Gene Expression Nervous System Atlas) program at the Rockefeller University (Gong et al, 2003) and were crossed on a C57BL/6 background for at least three generations. Knock-in mice expressing a mutated form of DARPP-32, in which Thr34 is replaced by Ala (DARPP-32 T34A mutant mice), and $\mathrm{Gnal}^{+/-}\left(\mathrm{G} \alpha_{\text {olf }}\right)$ heterozygous mice were generated as described in previous studies (Belluscio et al, 1998; Svenningsson et al, 2003) and were backcrossed for at least 10 generations on a C57BL/6 background. S6K1 knockout mice were generated via direct gene replacement with a neomycin cassette (previously described in Shima et al (1998) and were then outcrossed as described in Antion et al (2008). Animals were maintained in a 12-h light-dark cycle, in stable conditions of temperature $\left(22^{\circ} \mathrm{C}\right)$, with food and water ad libitum. All experiments were carried out in accordance with the guidelines of the Swedish Animal Welfare Agency, the French Agriculture and Forestry Ministry (decree 87849, license A75-05-22), or the guidelines of the New York University Institutional Animal Care and Use Committee.

\section{Drugs}

Haloperidol (0.5 mg/kg; Sigma-Aldrich, Stockholm, Sweden) was dissolved in saline containing $0.05 \%$ (vol/vol) acetic acid and the $\mathrm{pH}$ was adjusted to 6.0 with $1 \mathrm{M} \mathrm{NaOH}$. Clozapine ( $5 \mathrm{mg} / \mathrm{kg}$; Sigma-Aldrich, France) was dissolved in $0.9 \% \mathrm{NaCl}$. KW6002 $(3 \mathrm{mg} / \mathrm{kg})$ and SL327 $(50 \mathrm{mg} / \mathrm{kg})$, gifts from Dr Edilio Borroni (Hoffmann-La Roche, Basel, Switzerland), were suspended by sonication in a solution of $5 \%$ (vol/vol) Tween-80 in saline and administered 5 and $30 \mathrm{~min}$ before haloperidol, respectively. Rapamycin (LC Laboratories, Woburn, MA) ( $5 \mathrm{mg} / \mathrm{kg})$ was dissolved in a solution of $5 \%$ dimethylsulfoxide (DMSO), 15\% PEG400 , and 5\% Tween-20, and was administered (once per day) in a volume of $5 \mathrm{ml} / \mathrm{kg}$ body weight, starting 3 days before administration of haloperidol. All drugs were injected intraperitoneally (i.p.). Mice were habituated to handling for 3 consecutive days before the experiment. For the chronic experiment, mice were injected once daily with vehicle or haloperidol $(0.5 \mathrm{mg} / \mathrm{kg})$ for a period of 15 days and perfused 15 min after a challenge injection with vehicle or haloperidol.

\section{Primary Culture of Striatal Neurons}

Striata were dissected from embryos (E14) of OF1 mice (Charles River Laboratories France) and mechanically dissociated. Striatal cells were suspended in Neurobasal medium (Invitrogen) supplemented with B27 (Invitrogen), $0.5 \mathrm{mM}$ L-glutamine, $100 \mathrm{U} / \mathrm{ml}$ penicillin, and $100 \mu \mathrm{g} / \mathrm{ml}$ streptomycin, and then plated onto $35 \mathrm{~cm}$ culture dishes coated with poly-L-lysine, at $37^{\circ} \mathrm{C}$ in $5 \% \mathrm{CO}_{2}$. Every $3-4$ days, half of the medium was removed and replaced with fresh medium. After 16 days of culture, neurons were treated with drugs and incubations were stopped by replacing the medium with $0.2 \mathrm{ml}$ of boiling SDS (1\%, w/v). Protein concentration was determined by the bicinchoninic acid (BCA) assay kit (Pierce). Samples containing $30 \mu \mathrm{g}$ of protein were analyzed by electrophoresis on $12 \%$ polyacrylamide gels and were subjected to separation and western blotting as described below for brain samples.

\section{Immunofluorescence}

Mice were rapidly anaesthetized with pentobarbital (500 mg/kg, i.p.; Sanofi-Aventis, France) and transcardially perfused with $4 \%$ (wt/vol) paraformaldehyde in $0.1 \mathrm{M}$ sodium phosphate buffer ( $\mathrm{pH} 7.5$; Valjent et al, 2000). Brains were post-fixed overnight in the same solution and stored at $4{ }^{\circ} \mathrm{C}$. In all, $30-\mu \mathrm{m}$-thick sections were cut with a vibratome (Leica, France) and stored at $-20^{\circ} \mathrm{C}$ in a solution containing 30\% (vol/vol) ethylene glycol, 30\% (vol/vol) glycerol, and $0.1 \mathrm{M}$ sodium phosphate buffer, until they were processed for immunofluorescence. Brain regions corresponding to the dorsal striatum were identified using a mouse brain atlas (Franklin and Paxinos, 1997) and sections at $1.10 \mathrm{~mm}$ from bregma were taken. Free-floating sections were rinsed in Tris-buffered saline (TBS; $0.25 \mathrm{M}$

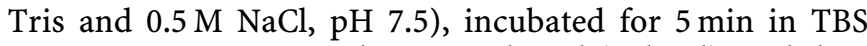
containing $3 \% \mathrm{H}_{2} \mathrm{O}_{2}$ and $10 \%$ methanol (vol/vol), and then rinsed three times for $10 \mathrm{~min}$ each in TBS. After $20 \mathrm{~min}$ incubation in $0.2 \%$ Triton $\mathrm{X}-100$ in TBS, sections were 
rinsed three times in TBS again. Finally, rpS6 phosphorylation was analyzed by incubating sections overnight with rabbit polyclonal antibodies against phospho-Ser235/236rpS6 (1:500; Cell Signalling Technology, Beverly, MA). NaF $(0.1 \mathrm{mM})$ was included in all buffers and incubation solutions. In some experiments, the expression of $\mathrm{G} \alpha_{\text {olf }}$ protein in wild-type and Gnal $+/$ - mice was assessed using rabbit polyclonal antibodies (1:500) (Herve et al, 2001). Sections were then rinsed three times for $10 \mathrm{~min}$ in TBS and incubated for $45 \mathrm{~min}$ with goat Cy3-coupled ( $1: 400$; Jackson Laboratory, Bar Harbor, ME) secondary antibody. Sections were rinsed for $10 \mathrm{~min}$ twice in TBS and twice in TB $(0.25 \mathrm{M}$ Tris) before mounting in Vectashield (Vector Laboratories, Burlingame, CA) or 1,4-diazabicyclo[2.2.2] octane (DABCO, Sigma-Aldrich, Sweden). Single- and double-labeled images from each region of interest were obtained bilaterally using sequential laser scanning confocal microscopy (Leica SP2 and Zeiss LSM510). Neuronal quantification was performed in $375 \times 375 \mu \mathrm{m}^{2}$ images by counting Cy3immunofluorescent nuclei (for phospho-Ser235/236-rpS6 immunolabeling). Cell counts were carried out by an observer unaware of the treatment received by the mice. A home-written program based on the Metamorph software (Molecular Devices, Sunnyvale, CA) was used to compute all parameters.

\section{Western Blotting}

Mice were killed by decapitation, their heads were cooled in liquid nitrogen for $6 \mathrm{~s}$, and the brains were removed. The striata were dissected out on an ice-cold surface, sonicated in $750 \mu \mathrm{l}$ of $1 \%$ SDS, and boiled for $10 \mathrm{~min}$. Aliquots $(5 \mu \mathrm{l})$ of the homogenate were used for protein determination using a BCA assay kit (Pierce Europe, Oud Beijerland, the Netherlands). Equal amounts of protein $(30 \mu \mathrm{g})$ for each sample were loaded onto $10 \%$ polyacrylamide gels. Proteins were separated by sodium dodecylsulfate-polyacrylamide gel electrophoresis and transferred overnight to PVDF membranes (Amersham Pharmacia Biotech, Uppsala, Sweden) (Towbin et al, 1979). The membranes were immunoblotted using antibodies against phospho-Ser235/236-rpS6, phospho-Thr389-S6K, phosphoThr202/Tyr204-ERK1/2 (Cell Signaling Technology, Beverly, MA), and phospho-Thr34-DARPP-32 (Snyder et al, 1992). Antibodies against rpS6, S6K (Cell Signaling Technology), and DARPP-32 (Hemmings and Greengard, 1986) that are not phosphorylation state specific were used to estimate the total amount of proteins. Detection was based on fluorescent secondary antibody binding and quantified using a Li-Cor Odyssey infrared fluorescent detection system (Li-Cor, Lincoln, NE) or with enhanced chemiluminescence reagent (GE Healthcare). The levels of each phosphoprotein were normalized for the amount of the corresponding total protein detected in the sample.

\section{Statistical Analysis}

Data were analyzed using one- or two-way ANOVA, and post hoc comparisons between groups were made using Bonferroni, or Newman-Keuls post hoc multiple comparison tests and $t$-tests with equal variances for groups of 2 , when relevant.

\section{RESULTS}

\section{Haloperidol Increases RpS6 Phosphorylation Selectively in D2R-Expressing Neurons}

Systemic administration of haloperidol at the dose of $0.5 \mathrm{mg} / \mathrm{kg}$, which has been previously shown to promote the phosphorylation of several proteins including PKA substrates (Bertran-Gonzalez et al, 2009; Håkansson et al, 2006), produced a twofold increase in the levels of phosphoSer235/236-rpS6, as determined by western blotting analysis of striatal tissue (Figure 1a). This effect peaked at $15 \mathrm{~min}$ post-injection and declined by $60 \mathrm{~min}$ (Figure 1a). Immunofluorescence analysis revealed a strong increase in the number of phospho-Ser235/236 rpS6-positive neurons in the dorsal striatum following haloperidol administration (Figure 1b).

In the dorsal striatum, D2Rs are selectively expressed by striatopallidal MSNs, whereas D1Rs are present in the other large group of projection neurons, which form the striatonigral pathway (Gerfen, 1992). To examine the effects of haloperidol on rpS6 phosphorylation in these two neuronal populations, we used transgenic mice expressing EGFP under the control of the promoter for the D2R or D1R (Drd2-EGFP and Drd1a-EGFP mice) (Gong et al, 2003; Valjent et al, 2009). We found that the increase in rpS6 phosphorylation induced by haloperidol $(0.5 \mathrm{mg} / \mathrm{kg})$ occurred specifically in D2R containing neurons (Figure 1c and d). Overall, these results are in line with the ability of this antipsychotic to act specifically at dopamine D2-type receptors and, therefore, to affect preferentially striatopallidal MSNs (Bateup et al, 2008; Bertran-Gonzalez et al, 2008, 2009). Interestingly, when administered chronically (one injection per day during 2 weeks) haloperidol lost the ability to increase rpS6 phosphorylation (Figure 1e and f). Therefore, rpS6 phosphorylation is induced selectively in striatopallidal MSNs in response to acute blockade of D2like receptor, but this effect appears to subside when the duration of treatment is extended.

We also examined the effect on rpS6 phosphorylation of clozapine, an atypical antipsychotic with low affinity for D2Rs. Clozapine $(5 \mathrm{mg} / \mathrm{kg})$ increased $\mathrm{rpS} 6$ phosphorylation at Ser235/236, selectively in D2R-expressing MSNs (Supplementary Figure S1). However, this effect was much lower and less sustained than that produced by haloperidol (cf. Figure 1c and d).

\section{Haloperidol-Induced Phosphorylation at Ser235/236 Does Not Require mTORC1 and S6K1 and is Independent of ERK}

S6Ks are primarily involved in the regulation of rpS6 (Bandi et al, 1993; Krieg et al, 1988; Pende et al, 2004; Ruvinsky et al, 2005). Therefore, we examined their involvement in haloperidol-induced phosphorylation at Ser235/236. Administration of the mTORC1 inhibitor, rapamycin, prevented phosphorylation of S6K at Thr389 (Figure 2c), but did not affect phosphorylation of rpS6 at Ser235/236 (Figure 2a and b). The effect of haloperidol was also tested in mice deficient for S6K1 (Pende et al, 2000) (Figure 2e). In line with the results obtained with rapamycin, we found that, in these animals, the ability of haloperidol to increase rpS6 phosphorylation at Ser235/236 was preserved (Figure 2d). 
a
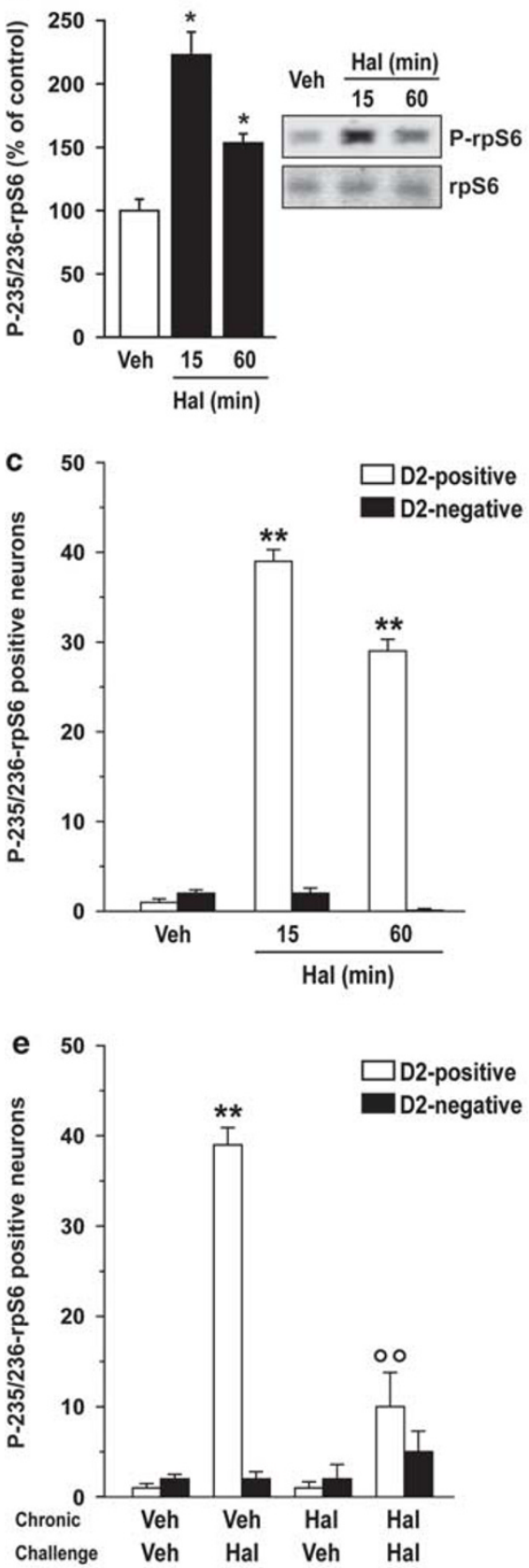

b

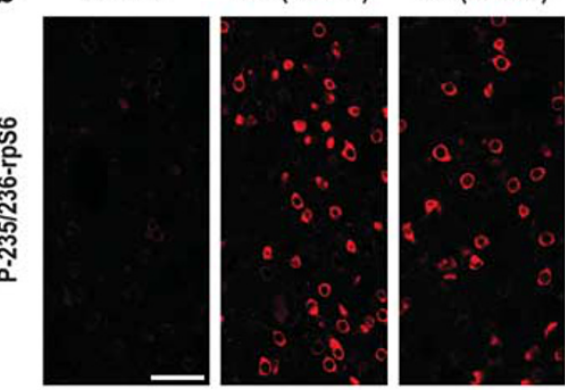

d

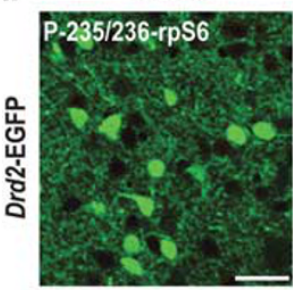

Haloperidol
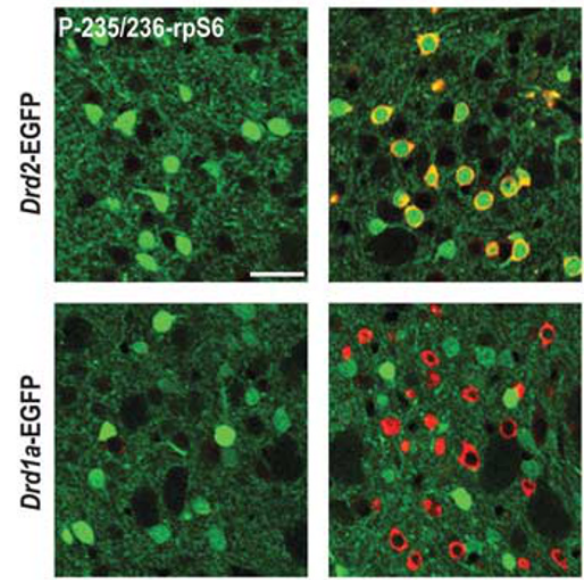

f

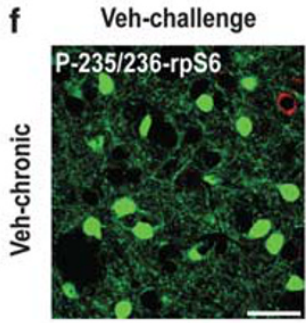

Hal-challenge
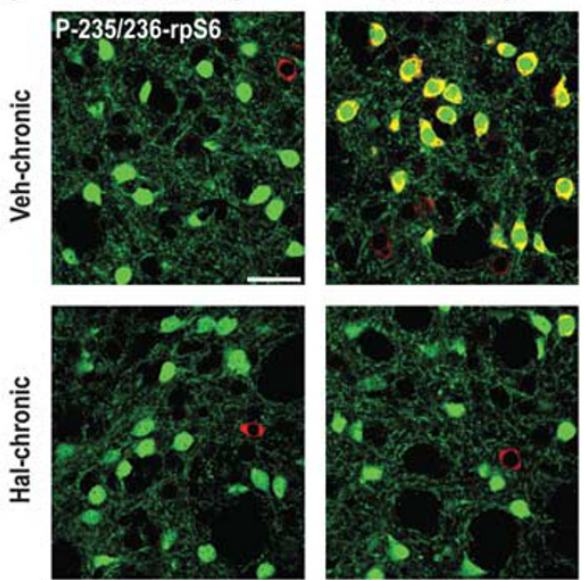

Figure I Effect of haloperidol on ribosomal protein S6 (rpS6) phosphorylation in striatal medium spiny neurons (MSNs). (a) Western blot analysis of phospho-Ser235/236-rpS6 (P-235/236-rpS6) in the striata of mice treated with vehicle (Veh) or haloperidol (Hal; $0.5 \mathrm{mg} / \mathrm{kg})$ and killed after 15 or $60 \mathrm{~min}$. Right panels show representative autoradiograms obtained using antibodies against P-235/236-rpS6 (upper) and total rpS6 (lower). Left panel is a summary of data represented as means \pm SEM $(n=5-7 ; * 0<0.05$ vs Veh). (b) Confocal sections of the dorsal striata, showing immunofluorescence for P-Ser235/236rpS6 in mice treated with Veh or Hal and perfused 15 or 60 min later. Scale bar $=40 \mu \mathrm{m}$. (c and d) Mice expressing enhanced green fluorescent protein (EGFP) in striatopallidal (Drd2-EGFP) or striatonigral (Drdla-EGFP) MSNs were treated with Veh or Hal (0.5 mg/kg) and perfused I5 or 60 min later. (c) Quantification of P-235/236-rpS6 immunoreactive neurons among EGFP-positive (D2-positive) or EGFP-negative (D2-negative) neurons in the dorsal striata of Veh or Hal treated Drd2-EGFP mice (** $<0.00$ I vs respective Veh). (d) Confocal sections of the dorsal striata of mice treated with Veh or Hal and perfused 15 min later, showing immunofluorescence for P-235/236-rpS6 in combination with EGFP fluorescence. Scale bar $=30 \mu \mathrm{m}$. (e and f) Mice expressing EGFP in striatopallidal (Drd2-EGFP) MSNs were repeatedly treated with Veh or Hal $(0.5 \mathrm{mg} / \mathrm{kg}$, one daily injection during 2 weeks) and perfused 15 min after a challenge injection of Veh or Hal. (e) Quantification of P-235/236-rpS6 immunoreactive neurons among EGFP-positive (D2-positive) or EGFPnegative (D2-negative) neurons in the dorsal striata of Drd2-EGFP mice treated chronically (2 weeks) with Veh or Hal and challenged with Veh or Hal $\left(* * p<0.00\right.$ I vs Veh; ${ }^{\circ 0} p<0.0$ I vs Hal). (f) Confocal sections of the dorsal striatum, showing immunofluorescence for P-235/236-rpS6 in combination with EGFP fluorescence. Scale bar $=30 \mu \mathrm{m}$.

Other protein kinases that phosphorylate rpS6 on Ser235/ 236 are the RSKs, which are activated by ERK (Roux et al, 2007). The ERK/RSK cascade accounts for the remaining phosphorylation of rpS6 on Ser235/236 observed in S6K1/S6K2 double knockout mice (Pende et al, 2004). We therefore examined the involvement of this pathway in rpS6 
a
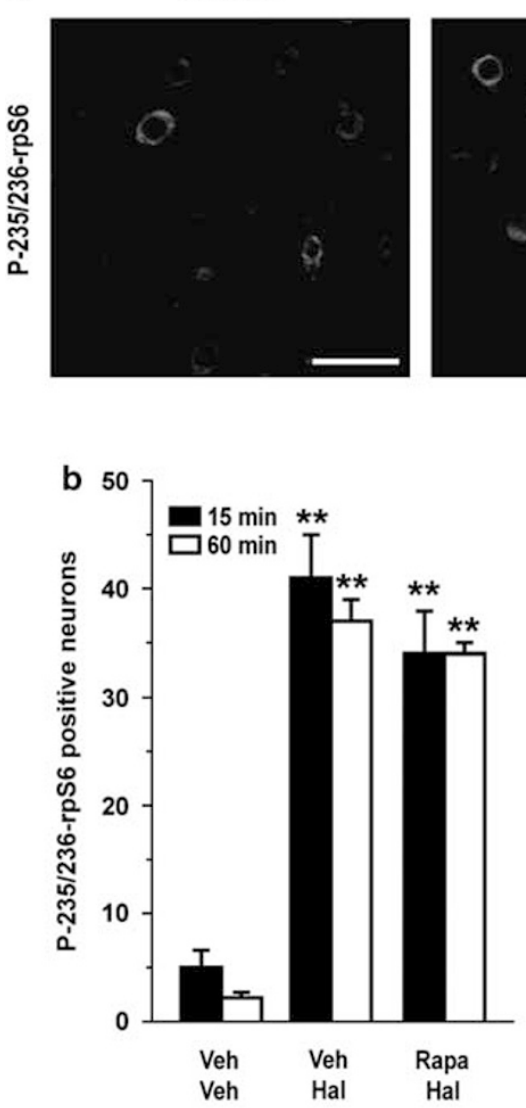

C

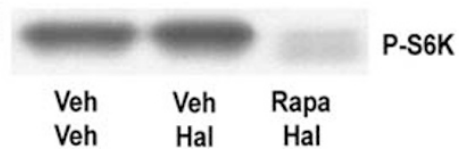

Veh-Hal

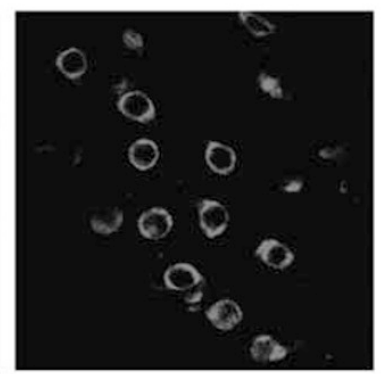

d

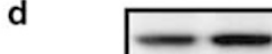

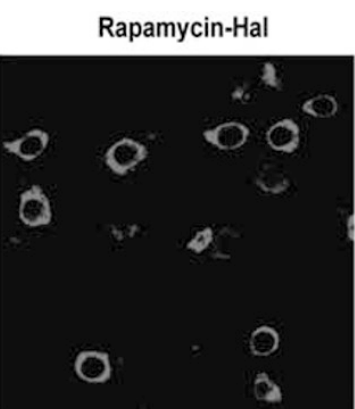
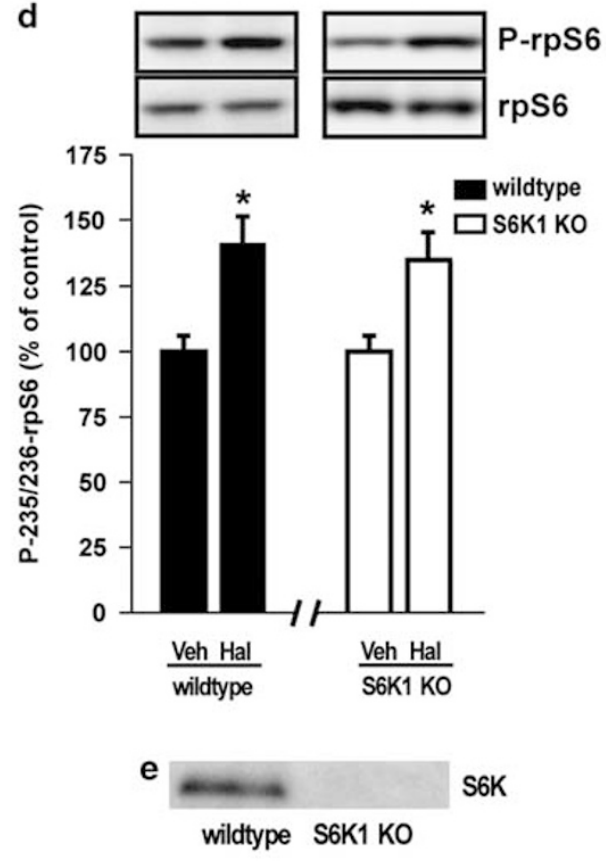

Figure 2 Blockade of mammalian target of rapamycin complex I (mTORCI)/p70 rpS6 kinase (S6K) signaling does not affect haloperidol-induced phosphorylation of ribosomal protein S6 (rpS6). Wild-type mice were treated with vehicle (Veh), haloperidol (Hal; $0.5 \mathrm{mg} / \mathrm{kg}$ ), or Hal plus rapamycin $(5 \mathrm{mg} / \mathrm{kg}$; administered once per day in a volume of $5 \mathrm{ml} / \mathrm{kg}$ body weight, starting 3 days before administration of Hal) and perfused after 15 or $60 \mathrm{~min}$. (a) Phospho-Ser235/236-rpS6 (P-235/236-rpS6) immunoreactivity in single confocal sections of the dorsal striata of mice treated with vehicle (Veh-Veh), haloperidol (Veh-Hal), or haloperidol plus rapamycin (Rapamycin-Hal) and perfused I 5 min later. Scale bar $=30 \mu \mathrm{m}$. (b) Quantification of P-235/236-rpS6 immunoreactive neurons in the dorsal striata of mice treated with Veh-Veh, Veh-Hal, or Rapamycin-Hal (*** $<0.00$ I vs Veh-Veh). (c) Wild-type mice were treated with Veh, Hal $(0.5 \mathrm{mg} / \mathrm{kg})$, or Hal plus rapamycin $(5 \mathrm{mg} / \mathrm{kg}$; see above) and were killed after I $5 \mathrm{~min}$. Representative autoradiogram showing the reduction of phospho-Thr389-S6K immunoreactivity in the striatum of a mouse treated with rapamycin. (d) Wild-type or S6KI knockout (KO) mice were treated with vehicle or haloperidol $(0.5 \mathrm{mg} / \mathrm{kg})$ and killed $15 \mathrm{~min}$ later. Striatal levels of P-235/236-rpS6 were determined by western blotting. Top panels show representative autoradiograms obtained using antibodies against P-235/236-rpS6 (upper) and total rpS6 (lower). Bottom panel is a summary of data represented as means \pm SEM ( $n=5$; * $p<0.05$ vs respective Veh). (e) Representative autoradiogram showing absence of S6K immunoreactivity in the striatum of an S6KI KO mice compared with a wild-type mouse.

phosphorylation. We found that blockade of ERK (Figure 3c), achieved using SL327 (an inhibitor of the mitogen-activated protein kinase/ERK kinase (MEK)), did not affect the increase in rpS6 phosphorylation produced by haloperidol (Figure $3 a$ and $b$ ).

\section{Haloperidol-Induced Phosphorylation of RpS6 Depends on Adenosine A2A Receptor-mediated Activation of $G \alpha_{\text {olf }}$}

The data presented above indicate that, in striatal neurons, the two major pathways known to control rpS6 phosphorylation at Ser235/236 are not involved in its regulation in response to haloperidol. Therefore, we examined the possible role of the cAMP-dependent cascade. In addition to D2Rs, striatopallidal MSNs express high levels of the adenosine $2 \mathrm{~A}$ receptor subtype (A2AR) for adenosine (Fink et al, 1992; Schiffmann et al, 1991). A2ARs are coupled to a $\mathrm{G} \alpha$ olf protein, which increases cAMP synthesis via activation of adenylyl cyclase (Corvol et al, 2001; Kull et al, 2000). The ability of D2R antagonists to promote cAMP signaling has been previously shown to depend in large part on intact A2AR-mediated transmission (Bertran-Gonzalez et al, 2009; Borgkvist and Fisone, 2007; Håkansson et al, 2006; Svenningsson et al, 2000). Therefore, we examined the effect produced by the selective A2AR antagonist, KW6002, on haloperidol-induced rpS6 phosphorylation. We found that blockade of A2ARs with $3 \mathrm{mg} / \mathrm{kg}$ of KW6002 reduced the effect of haloperidol on phospho-Ser235/236-rpS6 (Figure 4a and b).

A similar decrease in haloperidol-induced rpS6 phosphorylation was observed in $\mathrm{Gnal}^{+/-}$mice carrying a 

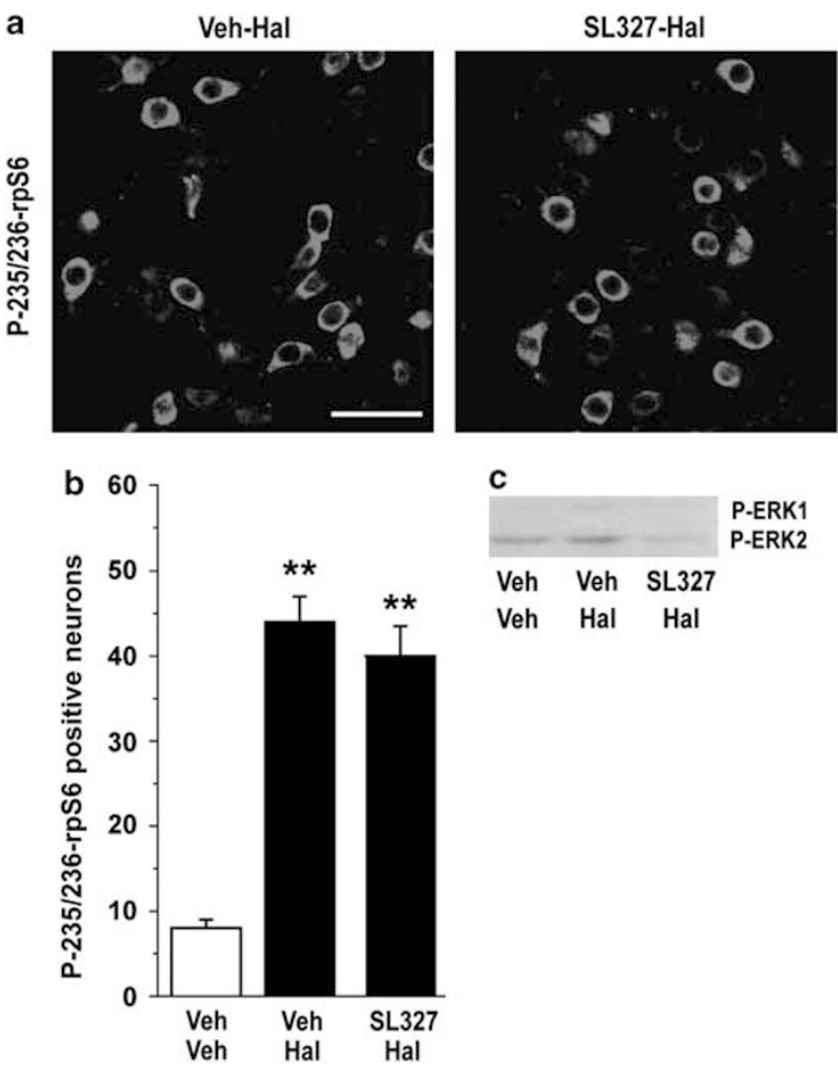

Figure 3 Effect of mitogen-activated protein kinase/ERK kinase (MEK) inhibition on haloperidol-induced phosphorylation of ribosomal protein S6 (rpS6). Mice were treated with vehicle (Veh), haloperidol ( $\mathrm{Hal} ; 0.5 \mathrm{mg} / \mathrm{kg}$ ), or Hal plus SL327 (50 mg/kg; administered $45 \mathrm{~min}$ before Hal) and perfused 15 min later. (a) Phospho-Ser235/236-rpS6 (P-235/236-rpS6) immunoreactivity in single confocal sections of the dorsal striata of mice treated with Hal or Hal plus SL327. Scale bar $=30 \mu \mathrm{m}$. (b) Quantification of P-235/236rpS6 immunoreactive neurons in the dorsal striata of mice treated with Veh, Hal, or Hal plus SL327 (** $<<0.0$ I vs Veh). (c) Mice were treated with Veh, Hal $(0.5 \mathrm{mg} / \mathrm{kg})$, or Hal plus SL327 $(50 \mathrm{mg} / \mathrm{kg}$; see above) and killed after $15 \mathrm{~min}$. Representative autoradiogram showing the reduction of phospho-ERK immunoreactivity in the striatum of a mouse treated with the MEK inhibitor.

heterozygous mutation of the gene encoding for $\mathrm{G} \alpha_{\mathrm{olf}}$, which reduces the levels of this protein in the striatum (Corvol et al, 2007) (Figure 5). This observation was particularly interesting, as in these mice the levels of $\mathrm{G} \alpha_{\mathrm{olf}}$ are decreased by approximately $50 \%$ (cf. Figure $5 \mathrm{a}$ ), which results in a large reduction of cAMP signaling (Corvol et al, 2007). Taken together, these results indicate that haloperidol increases rpS6 phosphorylation by removing the inhibitory tone normally exerted by D2Rs on A2ARmediated cAMP production.

We used striatal neurons in culture to further explore whether activation of A2ARs could regulate rpS6 phosphorylation on Ser235/236 through cAMP signaling. Application of the A2AR agonist 5'-( $N$-cyclopropyl)carboxamidoadenosine $(\mathrm{CPCA}, 200 \mu \mathrm{M})$ induced the phosphorylation of $\mathrm{rpS} 6$ on Ser235/236 in striatal neurons (Figure 6a). This effect was mediated by PKA, as it was abolished in the presence of the PKA inhibitor H-89 $(50 \mu \mathrm{M})$ (Figure 6a). Moreover, Sp-5,6-DCl-cBIMPS $(10 \mu \mathrm{M})$, a cAMP analog and PKA activator, induced a marked increase in rpS6 phosphorylation on Ser235/236 (Figure 6b). Thus, our results in vivo and
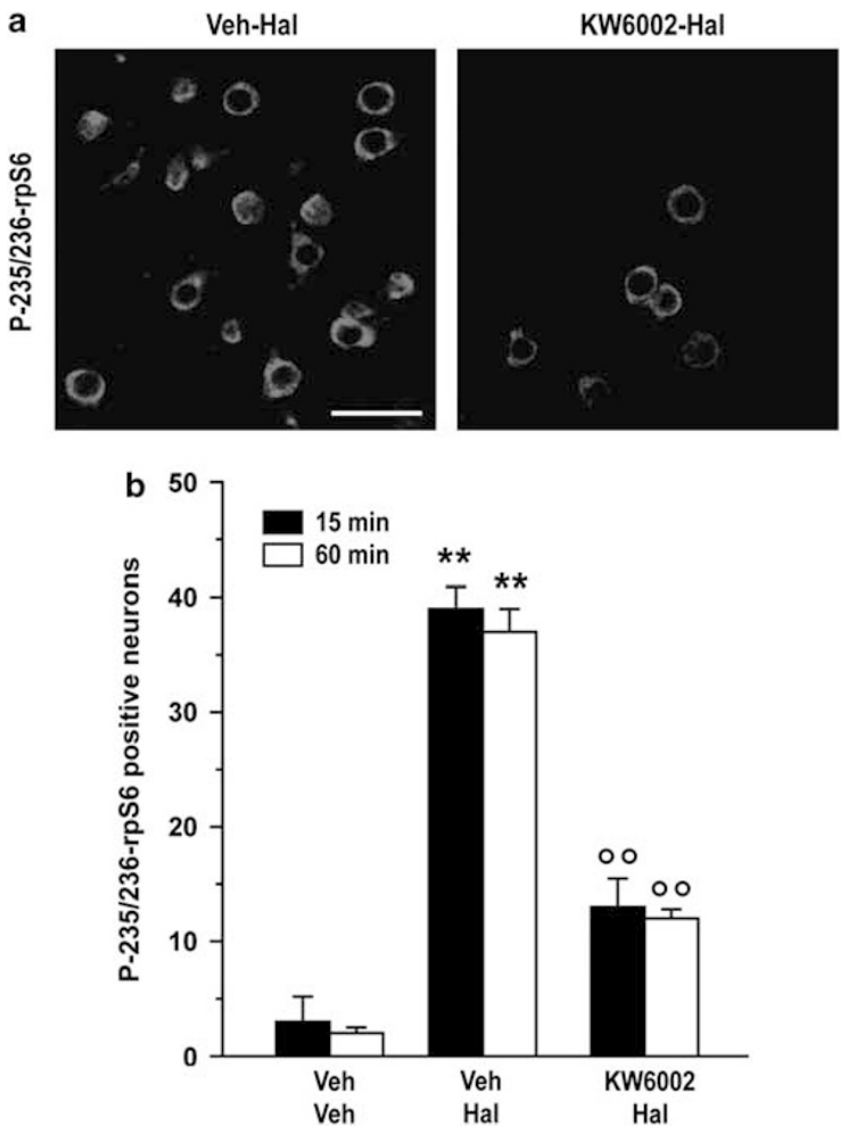

Figure 4 Effect of KW6002 on haloperidol-induced phosphorylation of ribosomal protein S6 (rpS6). Mice were treated with vehicle (Veh), haloperidol (Hal), or Hal plus KW6002 (3 mg/kg; administered 5 min before $\mathrm{Hal}$ ) and perfused 15 or $60 \mathrm{~min}$ later. (a) Phospho-Ser235/236-rpS6 (P-235/236-rpS6) immunoreactivity in single confocal sections of the dorsal striatum from mice treated with $\mathrm{Hal}$ or $\mathrm{Hal}$ plus KW6002. Scale bar $=30 \mu \mathrm{m}$. (b) Quantification of P-235/236-rpS6 immunoreactive neurons in single confocal sections of the dorsal striata of mice treated with Veh, Hal, or Hal plus KW6002 (** $p<0.0$ I vs Veh; ${ }^{\circ 0} p<0.0$ I vs Hal).

in vitro provide converging evidence that the effect of haloperidol on rpS6 Ser235/236 phosphorylation is mediated by activation of the cAMP pathway.

\section{Haloperidol-Induced Phosphorylation of RpS6 Depends on PKA-Mediated Activation of DARPP-32}

In the striatum, a large part of the effects produced by activation of cAMP signaling depends on DARPP-32 (Nairn et al, 2004). PKA-mediated phosphorylation at $\mathrm{Thr} 34$ converts DARPP-32 into an inhibitor of PP-1, thereby suppressing the dephosphorylation of numerous effector targets acting downstream of the cAMP/PKA cascade (Greengard, 2001). Haloperidol is known to increase DARPP-32 phosphorylation at Thr34 in vivo (Pozzi et al, 2003). Western blot analysis revealed a significant increase in the levels of phospho-Thr34-DARPP-32, determined in our experimental conditions 15 and $60 \mathrm{~min}$ after administration of haloperidol (Figure 7a). To assess the involvement of DARPP-32 in the haloperidol-mediated phosphorylation of rpS6, we used DARPP-32 T34A mutant mice, in which 
replacement of Thr34 by Ala prevents PKA-mediated phosphorylation (Figure $7 \mathrm{~b}$ ). We found that, in these mice, haloperidol did not produce any change in the state of phosphorylation of rpS6 (Figure 7c and d). These data point to the PKA/DARPP-32 signaling pathway as a major modulator of rpS6 in striatal neurons and indicate that phosphorylation at Ser235/236 is under the control of PP-1.

a

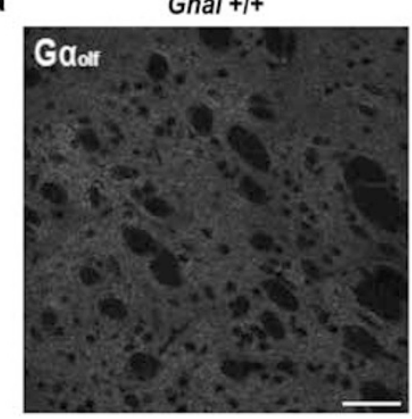

b
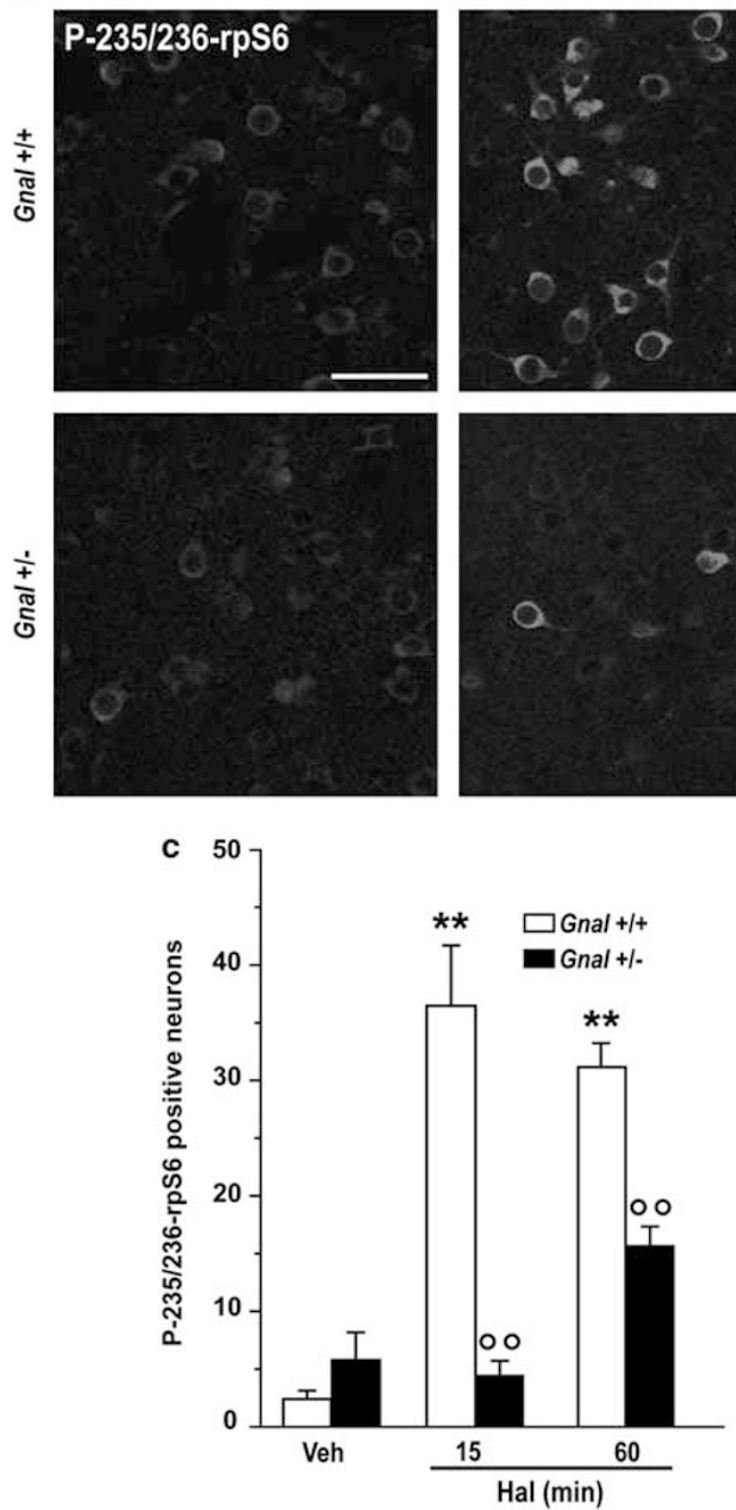

\section{DISCUSSION}

This study demonstrates that administration of the antipsychotic drug and D2R antagonist, haloperidol, promotes phosphorylation of rpS6 at Ser235/236, specifically at the level of the MSNs of the indirect, striatopallidal pathway. They also show that this effect is exerted by promoting A2AR-mediated activation of the cAMP/DARPP32 signaling cascade and that it does not involve activation of S6K, or ERK/RSK.

In striatopallidal neurons, blockade of D2Rs increases the state of phosphorylation of several substrates of PKA (Bertran-Gonzalez et al, 2008, 2009; Håkansson et al, 2006; Li et al, 2004; Pozzi et al, 2003). This effect has been attributed to the removal of the inhibitory tone exerted by D2Rs on adenylyl cyclase, which leads to the accumulation of cAMP and activation of PKA. The ability of D2R antagonists, including haloperidol, to promote cAMP/PKA signaling depends on A2ARs (Bertran-Gonzalez et al, 2009; Borgkvist and Fisone 2007; Håkansson et al, 2006; Svenningsson et al, 2000), which maintain basal adenylyl cyclase activity via activation of $\mathrm{G} \alpha_{\text {olf }}$ (Corvol et al, 2001). These results, showing that blockade of A2ARs or reduction of the levels of $\mathrm{G} \alpha_{\text {olf }}$ prevent the haloperidol-induced increase in Ser235/236 phosphorylation, indicate the
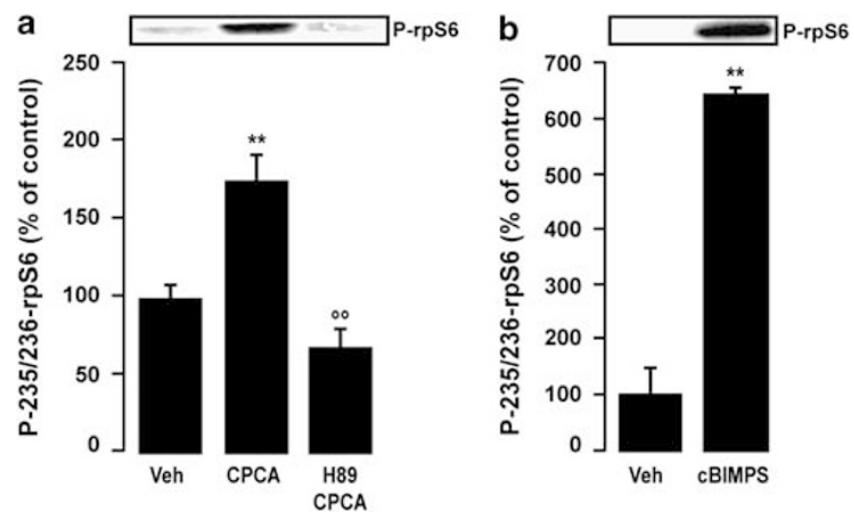

Figure 6 Effect of protein kinase A (PKA) signaling on ribosomal protein S6 (rpS6) phosphorylation. Western blot analysis of phospho-Ser235/236rpS6 in striatal neurons in culture. Top panels show representative autoradiograms. Bottom panels are a summary of data represented as means $\pm \operatorname{SEM}(n=4)$. (a) Striatal neurons were treated for $15 \mathrm{~min}$ with vehicle (Veh), the A2AR agonist 5'-(N-cyclopropyl)carboxamidoadenosine (CPCA, $10 \mu \mathrm{M})$ or CPCA plus the PKA inhibitor $\mathrm{H}-89$ dihydrochloride hydrate $(50 \mu \mathrm{M}$, added $15 \mathrm{~min}$ before CPCA). (b) Striatal neurons were treated for $15 \mathrm{~min}$ with $\mathrm{Veh}$ or the cAMP analog Sp-5,6-DCl-cBIMPS (cBIMPS, $200 \mu \mathrm{M})$. (*** $<<0.01$ vs Veh; ${ }^{\circ 0} p<0.01$ vs CPCA).

Figure $5 \quad G \alpha_{o l f}$-mediated signaling is required for haloperidol-induced ribosomal protein S6 (rpS6) phosphorylation. Wild-type (Gnal ${ }^{+/+}$) and $\mathrm{Gnal}^{+1-}$ mice were treated with haloperidol $(0.5 \mathrm{mg} / \mathrm{kg})$ and perfused 15 and 60 min later. (a) $\mathrm{G} \alpha_{\text {olf }}$ immunoreactivity in single confocal sections of the dorsal striatum from a wild-type (WT) or a Gnal heterozygous (Gnal ${ }^{+/-}$) mouse. Note the decrease in $\mathrm{G} \alpha_{\text {olf }}$ immunoreactivity in the striatum of the $\mathrm{Gnal}^{+1-}$ mouse. Scale bar $=50 \mu \mathrm{m}$. (b) Phospho-Ser235/236-rpS6 (P-235/236-rpS6) immunoreactivity in single confocal sections of the dorsal striatum of $\mathrm{Gnal}^{+/+}$or Gnal ${ }^{+/-}$mice. Scale bar $=30 \mu \mathrm{m}$. (c) Quantification of P-235/236-rpS6 immunoreactive neurons in the striata of $\mathrm{Gnal}^{+/+}$ and $\mathrm{Gnal}^{+/-}$mice 15 and $60 \mathrm{~min}$ after administration of vehicle (Veh) or haloperidol (Hal) $\left({ }^{*} \mathrm{p} p<0.01\right.$ vs Veh; ${ }^{\circ 0} p<0.01$ vs Gnal $^{+/+}$). 
importance of PKA in this phenomenon. This idea is further supported by the observation that, in cultured striatal neurons, A2AR-mediated increase in Ser235/236 phosphorylation is blocked by PKA inhibition and is mimicked by

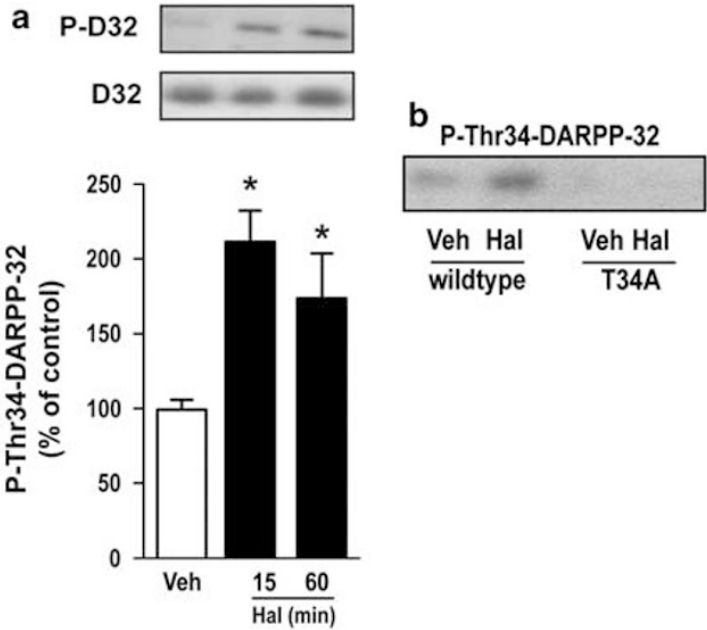

C

Vehicle
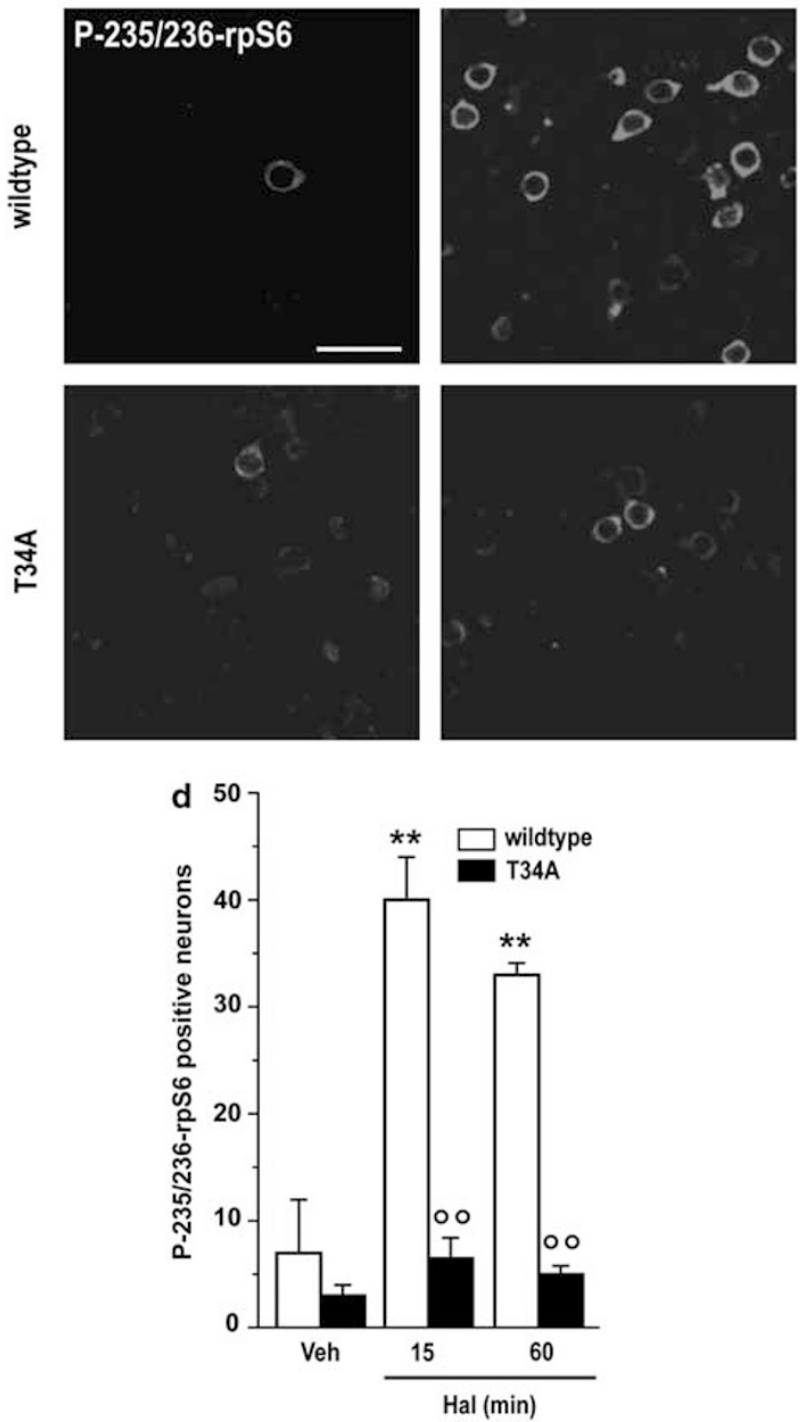

PKA activation. These observations are in line with the recent identification of PKA as a third in vivo rpS6 kinase in pancreatic $\beta$-cells (Moore et al, 2009).

The ability of the cAMP/PKA signaling pathway to regulate the activity of downstream target proteins depends on concomitant phosphorylation of DARPP-32 at Thr34, which suppresses protein dephosphorylation via inhibition of PP-1 (Greengard, 2001). Thus, mutation of DARPP-32 at the PKA phosphorylation site, Thr34, prevents the ability of haloperidol and other D2R antagonists to increase the state of phosphorylation of the GluR1 subunit of glutamate AMPA receptors and of histone $\mathrm{H} 3$ (Bertran-Gonzalez et al, 2009; Håkansson et al, 2006). The present data indicate that a similar mechanism is involved in the regulation of rpS6 phosphorylation exerted by haloperidol at Ser235/236. Thus, the effect of haloperidol depends not only on increased PKA-catalyzed phosphorylation, but also on decreased dephosphorylation exerted by phospho-Thr34DARPP-32, via inhibition of PP-1. In support of this type of regulation, it has been previously proposed that PP-1 acts as an S6 phosphatase (Belandia et al, 1994).

The effect of haloperidol on rpS6 phosphorylation at Ser235/236 is exerted independently of S6K. Thus, administration of rapamycin, which suppresses S6K activity, or deletion of S6K1, does not prevent the ability of the D2R antagonist to promote rpS6 phosphorylation.

It has been shown that the ERK/RSK signaling pathway regulates $\mathrm{rpS} 6$ phosphorylation via activation of mTORC1 and S6K (Ma et al, 2005; Roux et al, 2004). Moreover, ERK has been proposed to regulate rpS6 phosphorylation independently of mTORC1, via RSK-catalyzed phosphorylation at Ser235/236 (Roux et al, 2007). Our data show that blockade of ERK, achieved with the MEK inhibitor SL327, does not modify the ability of haloperidol to increase rpS6 phosphorylation. This shows that the modest increase of ERK phosphorylation produced by haloperidol in striatopallidal MSNs (Bertran-Gonzalez et al, 2008, 2009) is not involved in the regulation of rpS6.

Work performed in a mouse model of Parkinson's disease shows that activation of D1Rs increases the phosphorylation of rpS6 at Ser235/236. This effect, which is exerted selectively in the MSNs of the direct pathway, depends on concomitant activation of ERK (Santini et al, 2009).

Figure 7 Mutation of Thr34 to Ala in dopamine- and CAMP-regulated phosphoprotein of $32 \mathrm{kDa}$ (DARPP-32) prevents haloperidol-induced histone $\mathrm{H} 3$ phosphorylation. Wild-type and T34A mutant mice were treated with vehicle (Veh) or haloperidol ( $\mathrm{Hal} ; 0.5 \mathrm{mg} / \mathrm{kg}$ ) and perfused I 5 and 60 min later. (a) Western blot analysis of phospho-Thr34-DARPP-32 (P-DARPP-32) in the striata of wild-type mice treated with haloperidol $(0.5 \mathrm{mg} / \mathrm{kg})$ and killed after 15 or $60 \mathrm{~min}$. Top panels shows representative autoradiograms obtained using antibodies against P-DARPP-32 (upper) and total DARPP-32 (lower). Bottom panel is a summary of data represented as means \pm SEM $(n=5-7) \quad(* p<0.05$ vs vehicle). (b) Representative autoradiogram confirming the absence of P-DARPP-32 immunoreactivity in the striata of mice treated with Veh or Hal. (c and d) Wild-type or T34A DARPP-32 mutant mice were treated with Veh or Hal and perfused 15 or 60 min later. (c) Phospho-Ser235/236-ribosomal protein S6 (P-235/236rpS6) immunoreactivity in single confocal sections of the dorsal striata of wild-type or T34A mutant mice. Scale bar $=30 \mu \mathrm{m}$. (d) Quantification of P-235/236-rpS6 immunoreactive neurons in the dorsal striatum, 15 or 60 min after administration of Veh or Hal to wild-type or T34A DARPP-32 mutant mice (T34A) (*** $p<0.01$ vs Veh; ${ }^{\circ} p<0.0$ I vs wild type). 
Therefore, it appears that, in the striatum, the state of phosphorylation of rpS6 at the level of the two major neuronal populations (ie, the MSNs of the direct and indirect pathway) is controlled by distinct signaling mechanisms.

The ability of haloperidol to increase the state of phosphorylation of $\mathrm{rpS6}$ in the dorsal striatum represents a novel mechanism potentially implicated in the action of typical antipsychotic drugs. In particular, these results suggest that the motor side effects produced by these substances may be linked to changes in the efficiency of mRNA translation occurring in striatopallidal MSNs. In this regard, it is interesting to note that clozapine, an atypical antipsychotic with low liability for motor complications, produces a much more modest effect on rpS6 phosphorylation in comparison to haloperidol. In line with this observation, it has been shown that haloperidol, but not clozapine, increases the expression of $c$-fos in the dorsal striatum (Robertson and Fibiger, 1992; Wan et al, 1995). It is therefore possible that the emergence of tardive dyskinesia and parkinsonism in response to administration of typical antipsychotic drugs is related to modifications in the activity of striatal MSNs produced through a coordinated action on transcriptional and translational processes.

In conclusion, this study shows that the typical antipsychotic, haloperidol, increases the state of phosphorylation of rpS6 in striatopallidal MSNs independently of mTORC1/S6K and ERK/RSK signaling, through activation of cAMP signaling. The data presented support a model in which blockade of D2Rs promotes PKA-catalyzed phosphorylation of Ser235/236 and suppresses PP-1-mediated dephosphorylation via DARPP-32. They also raise the possibility that antipsychotic drugs and D2R antagonists affect striatal transmission not only through control of transcriptional process, but also via changes in translational efficiency.

\section{ACKNOWLEDGEMENTS}

This work was supported by Swedish Research Council Grants 20715 and 13482, the Wenner-Gren Foundations and the Agence Nationale de la Recherche (ANR) in the frame of Era-Net NEURON (project ANR-08-NEUR-006-01) (to GF), the Fondation pour la Recherche Médicale (FRM) and Grant ANR-08-BLAN-0287 (to JAG), and the National Institutes of Health Grants NS034007 and NS047384 (to EK). SL was a recipient of a postdoctoral fellowship from the FEBS. ABO was supported by the foundation Blanceflor BoncompagniLudovisi, née Bildt. We thank Dr Paul Greengard for providing the T34A DARPP-32 mutant mice.

\section{DISCLOSURE}

The authors declare no conflict of interest.

\section{REFERENCES}

Albin RL, Young AB, Penney JB (1989). The functional anatomy of basal ganglia disorders. Trends Neurosci 12: 366-375.

Antion MD, Merhav M, Hoeffer CA, Reis G, Kozma SC, Thomas G et al (2008). Removal of $\mathrm{S} 6 \mathrm{~K} 1$ and $\mathrm{S} 6 \mathrm{~K} 2$ leads to divergent alterations in learning, memory, and synaptic plasticity. Learn Mem 15: 29-38.
Bandi HR, Ferrari S, Krieg J, Meyer HE, Thomas G (1993). Identification of $40 \mathrm{~S}$ ribosomal protein S6 phosphorylation sites in Swiss mouse 3T3 fibroblasts stimulated with serum. J Biol Chem 268: 4530-4533.

Bateup HS, Svenningsson P, Kuroiwa M, Gong S, Nishi A, Heintz N et al (2008). Cell type-specific regulation of DARPP-32 phosphorylation by psychostimulant and antipsychotic drugs. Nat Neurosci 11: 932-939.

Belandia B, Brautigan D, Martin-Perez J (1994). Attenuation of ribosomal protein S6 phosphatase activity in chicken embryo fibroblasts transformed by Rous sarcoma virus. Mol Cell Biol 14: 200-206.

Belluscio L, Gold GH, Nemes A, Axel R (1998). Mice deficient in G(olf) are anosmic. Neuron 20: 69-81.

Bertran-Gonzalez J, Bosch C, Maroteaux M, Matamales M, Herve D, Valjent E et al (2008). Opposing patterns of signaling activation in dopamine D1 and D2 receptor-expressing striatal neurons in response to cocaine and haloperidol. J Neurosci 28: 5671-5685.

Bertran-Gonzalez J, Hakansson K, Borgkvist A, Irinopoulou T, Brami-Cherrier K, Usiello A et al (2009). Histone H3 phosphorylation is under the opposite tonic control of dopamine D2 and adenosine A2A receptors in striatopallidal neurons. Neuropsychopharmacology 34: 1710-1720.

Borgkvist A, Fisone G (2007). Psychoactive drugs and regulation of the cAMP/PKA/DARPP-32 cascade in striatal medium spiny neurons. Neurosci Biobehav Rev 31: 79-88.

Corvol JC, Studler JM, Schonn JS, Girault JA, Herve D (2001). Galpha(olf) is necessary for coupling D1 and A2a receptors to adenylyl cyclase in the striatum. J Neurochem 76: 1585-1588.

Corvol JC, Valjent E, Pascoli V, Robin A, Stipanovich A, Luedtke $\mathrm{RR}$ et al (2007). Quantitative changes in G $\alpha$ olf protein levels, but not D1 receptor, alter specifically acute responses to psychostimulants. Neuropsychopharmacology 32: 1109-1121.

Costa-Mattioli M, Sossin WS, Klann E, Sonenberg N (2009). Translational control of long-lasting synaptic plasticity and memory. Neuron 61: 10-26.

Creese I, Burt DR, Snyder SH (1976). Dopamine receptor binding predicts clinical and pharmacological potencies of anti-schizophrenic drugs. Science 192: 481-483.

Fink JS, Weaver DR, Rivkees SA, Peterfreund RA, Pollack AE, Adler EM et al (1992). Molecular cloning of the rat A2 adenosine receptor: selective co-expression with D2 dopamine receptor in rat striatum. Mol Brain Res 14: 186-195.

Franklin KBJ, Paxinos G (1997). The Mouse Brain in Stereotaxic Coordinates. Academic Press: San Diego, CA.

Gerfen CR (1992). The neostriatal mosaic: multiple levels of compartmental organization in the basal ganglia. Ann Rev Neurosci 15: 285-320.

Gong S, Zheng C, Doughty ML, Losos K, Didkovsky N, Schambra UB et al (2003). A gene expression atlas of the central nervous system based on bacterial artificial chromosomes. Nature 425: 917-925.

Greengard P (2001). The neurobiology of slow synaptic transmission. Science 294: 1024-1030.

Håkansson K, Galdi S, Hendrick J, Snyder G, Greengard P, Fisone G (2006). Regulation of phosphorylation of the GluR1 AMPA receptor by dopamine D2 receptors. J Neurochem 96: 482-488.

Hemmings HCJ, Greengard P (1986). DARPP-32, a dopamine- and adenosine $3^{\prime}: 5^{\prime}$-monophosphate-regulated phosphoprotein: regional, tissue, and phylogenetic distribution. J Neurosci 6: 1469-1481.

Herve D, Le Moine C, Corvol JC, Belluscio L, Ledent C, Fienberg AA et al (2001). Galpha(olf) levels are regulated by receptor usage and control dopamine and adenosine action in the striatum. J Neurosci 21: 4390-4399.

Konradi C, Heckers S (1995). Haloperidol-induced Fos expression in striatum is dependent upon transcription factor cyclic AMP response element binding protein. Neuroscience 65: 1051-1061. 
Krieg J, Hofsteenge J, Thomas G (1988). Identification of the $40 \mathrm{~S}$ ribosomal protein S6 phosphorylation sites induced by cycloheximide. J Biol Chem 263: 11473-11477.

Kull B, Svenningsson P, Fredholm BB (2000). Adenosine A(2A) receptors are colocalized with and activate $\mathrm{g}(\mathrm{olf})$ in rat striatum. Mol Pharmacol 58: 771-777.

Li J, Guo Y, Schroeder FA, Youngs RM, Schmidt TW, Ferris C et al (2004). Dopamine D2-like antagonists induce chromatin remodeling in striatal neurons through cyclic AMP-protein kinase A and NMDA receptor signaling. J Neurochem 90: 1117-1131.

Ma L, Chen Z, Erdjument-Bromage H, Tempst P, Pandolfi PP (2005). Phosphorylation and functional inactivation of TSC2 by Erk implications for tuberous sclerosis and cancer pathogenesis. Cell 121: 179-193.

Moore CE, Xie J, Gomez E, Herbert TP (2009). Identification of cAMP-dependent kinase as a third in vivo ribosomal protein S6 kinase in pancreatic beta-cells. J Mol Biol 389: 480-494.

Nairn AC, Svenningsson P, Nishi A, Fisone G, Girault JA, Greengard P (2004). The role of DARPP-32 in the actions of drugs of abuse. Neuropharmacology 47: 14-23.

Pende M, Kozma SC, Jaquet M, Oorschot V, Burcelin R, Le Marchand-Brustel Y et al (2000). Hypoinsulinaemia, glucose intolerance and diminished beta-cell size in S6K1-deficient mice. Nature 408: 994-997.

Pende M, Um SH, Mieulet V, Sticker M, Goss VL, Mestan J et al (2004). S6K1(-I-)/S6K2(-/-) mice exhibit perinatal lethality and rapamycin-sensitive $5^{\prime}$-terminal oligopyrimidine mRNA translation and reveal a mitogen-activated protein kinasedependent S6 kinase pathway. Mol Cell Biol 24: 3112-3124.

Pozzi L, Hakansson K, Usiello A, Borgkvist A, Lindskog M, Greengard P et al (2003). Opposite regulation by typical and atypical anti-psychotics of ERK1/2, CREB and Elk-1 phosphorylation in mouse dorsal striatum. J Neurochem 86: 451-459.

Robertson GS, Fibiger HC (1992). Neuroleptics increase c-fos expression in the forebrain: contrasting effects of haloperidol and clozapine. Neuroscience 46: 315-328.

Roux PP, Ballif BA, Anjum R, Gygi SP, Blenis J (2004). Tumorpromoting phorbol esters and activated Ras inactivate the tuberous sclerosis tumor suppressor complex via p90 ribosomal S6 kinase. Proc Natl Acad Sci USA 101: 13489-13494.

Roux PP, Shahbazian D, Vu H, Holz MK, Cohen MS, Taunton J et al (2007). RAS/ERK signaling promotes site-specific ribosomal protein S6 phosphorylation via RSK and stimulates capdependent translation. J Biol Chem 282: 14056-14064.

Ruvinsky I, Meyuhas O (2006). Ribosomal protein S6 phosphorylation: from protein synthesis to cell size. Trends Biochem Sci 31: $342-348$.
Ruvinsky I, Sharon N, Lerer T, Cohen H, Stolovich-Rain M, Nir T et al (2005). Ribosomal protein S6 phosphorylation is a determinant of cell size and glucose homeostasis. Genes Dev 19: 2199-2211.

Santini E, Heiman M, Greengard P, Valjent E, Fisone G (2009). Inhibition of mTOR signaling in Parkinson's disease prevents L-DOPA-induced dyskinesia. Sci Signal 2: ra36.

Schiffmann SN, Jacobs O, Vanderhaegen JJ (1991). Striatal restricted adenosine A2 receptor (RDC8) is expressed by enkephalin but not by substance $\mathrm{P}$ neurons: an in situ hybridization histochemistry study. J Neurochem 57: 1062-1067.

Shima H, Pende M, Chen Y, Fumagalli S, Thomas G, Kozma SC (1998). Disruption of the $\mathrm{p} 70(\mathrm{~s} 6 \mathrm{k}) / \mathrm{p} 85$ (s6k) gene reveals a small mouse phenotype and a new functional S6 kinase. EMBO J 17: 6649-6659.

Snyder GL, Girault JA, Chen JY, Czernik AJ, Kebabian JW, Nathanson JA et al (1992). Phosphorylation of DARPP-32 and protein phosphatase inhibitor-1 in rat choroid plexus: regulation by factors other than dopamine. J Neurosci 12: 3071-3083.

Stoof JC, Kebabian JW (1981). Opposing roles for D-1 and D-2 dopamine receptors in efflux of cyclic AMP from rat neostriatum. Nature 294: 366-368.

Sturgill TW, Ray LB, Erikson E, Maller JL (1988). Insulinstimulated MAP-2 kinase phosphorylates and activates ribosomal protein S6 kinase II. Nature 334: 715-718.

Svenningsson P, Lindskog M, Ledent C, Parmentier M, Greengard $\mathrm{P}$, Fredholm BB et al (2000). Regulation of the phosphorylation of the dopamine- and cAMP-regulated phosphoprotein of $32 \mathrm{kDa}$ in vivo by dopamine D1, dopamine D2, and adenosine A2A receptors. Proc Natl Acad Sci USA 97: 1856-1860.

Svenningsson P, Tzavara ET, Carruthers R, Rachleff I, Wattler S, Nehls M et al (2003). Diverse psychotomimetics act through a common signaling pathway. Science 302: 1412-1415.

Towbin H, Staehelin T, Gordon J (1979). Electrophoretic transfer of proteins from polyacrylamide gels to nitrocellulose sheets: procedure and some applications. Proc Natl Acad Sci USA 76: 4350-4354.

Valjent E, Bertran-Gonzalez J, Herve D, Fisone G, Girault JA (2009). Looking BAC at striatal signaling: cell-specific analysis in new transgenic mice. Trends Neurosci 32: 538-547.

Valjent E, Corvol JC, Pages C, Besson MJ, Maldonado R, Caboche J (2000). Involvement of the extracellular signal-regulated kinase cascade for cocaine-rewarding properties. J Neurosci 20: 8701-8709.

Wan W, Ennulat DJ, Cohen BM (1995). Acute administration of typical and atypical antipsychotic drugs induces distinctive patterns of Fos expression in the rat forebrain. Brain Res 688: 95-104.

Supplementary Information accompanies the paper on the Neuropsychopharmacology website (http://www.nature.com/npp) 